\title{
HUBUNGAN TINGKAT PENGETAHUAN DENGAN SIKAP \\ ORANG TUA TENTANG TOILET TRAINING PADA \\ ANAK USIA TODDLER (1-3 TAHUN) \\ (Di PAUD PELITA ILMU Kelurahan Mrican Kecamatan Mojoroto)
}

Erna Susilowati, S.Kep.Ns.M.Gizi ${ }^{1}$, Riris Rinjarti Pratiwi ${ }^{2}$

Akademi Keperawatan Dharma Husada Kediri Jawa Timur

\section{ABSTRACT}

Less knowledge and attitudes of parents about toilet training cause parents give negative attitudes in children. Nurses role as educators is to facilitate parents to get information about the proper method or manner do toilet training in health education. This research aims to determine the relationship is there a knowledge with the attitudes of parents about toilet training.

This research is a correlation with the population of all parents who have children aged 1-3 years in getting the samples in this research conducted with 23 respondents Total Sampling. The variable in this research is the dependent variable level of knowledge about toilet training and independent variable attitudes of parents on toilet training with the Spearman Rank Test statistic obtained significant results with values of 0.05 in getting $P$ value 0.015

The research results get $H 0$ rejected $H 1$ received by this there is a correlation between the level of knowledge with the attitudes of parents about toilet training supported with the results of the research (91.3\%) had good knowledge level of (65.2\%) largely supportive attitude about toilet training.

The conclusion from this research that there is a relationship between the level of knowledge with the attitude of a good parent as well as the support of the toilet training of children. The high the level of knowledge, the attitude is also getting better. Suggestion in the hope that nurses can implement awareness toilet training of children by parents.

Keywords: Knowledge, Attitude, Toilet Training

1 | Jurnal Kebidanan Dharma Husada Vol. 5, No. 1 April 2016 


\section{PENDAHULUAN}

Anak usia toddler harus mampu mengenali rasa untuk mengeluarkan dan menahan eliminasi serta mampu mengkomunikasikan sensasi Buang air kecil (BAK) dan Buang air besar (BAB) kepada orang tua (Alexandra, 2008). Pada fase toddler anak dituntut untuk menyelesaikan tugas perkembangan yaitu anak mampu mengatakan ingin buang air besar, menahan $\mathrm{BAB} / \mathrm{BAK}$, mengeluarkan $\mathrm{BAB} / \mathrm{BAK}$ sesuai kendali anak. Fase ini harus tercapai maksimal sampai anak berumur 3 tahun. Tugas perkembangan ini akan berhasil bila didukung oleh lingkungan, pengetahuan dan sikap orang tua yang baik.

Dalam mengajarkan toilet training dibutuhkan metode atau cara yang tepat sehingga mudah dimengerti oleh anak serta perlu kesabaran bagi orang tua untuk melatih anak tahap demi tahap sehingga toilet training berhasil diterapkan pada anak(Armawati, 2011). Penggunaan metode yang tepat akan mempengaruhi keberhasilan orang tua dalam mengajarkan konsep toilet training pada anak. Pengetahuan tentang toilet training sangat penting untuk orang tua, hal ini akan berpengaruh pada penerapan toilet training pada anak.

$31 \%$ orang tua mulai mengajarkarkan toilet training pada anak usia 18-22 bulan, $27 \%$ mulai di usia $23-27$ bulan, dan $16 \%$ di usia $28-32$ bulan dan $22 \%$ di usia 32 bulan ke atas. Orang tua harus mengetahui apakah anaknya sudah siap untuk di ajarkan toilet training sehingga dalam pengajaran tidak membutuhkan waktu yang lama (Gilbert, 2003). Blum (2003) menyatakan bahwa toilet training yang diajarkan pada sekelompok anak usia $<24$ bulan, $68 \%$ dapat menyelesaikannya sebelum usia 3 tahun. Sedangkan pada sekelompok yang berusia $>24$ bulan, hanya $54 \%$ yang mampu menyelesaikannya sebelum 3 tahun. Sebuah studi di Belgia juga menghasilkan pendapat bahwa pelaksanaan toilet training yang lebih dini akan mempercepat tercapainya kemampuan kontrol kemih (Blum, 2003).

Hasil survey dari studi pendahuluan yang sudah di laksanakan pada tanggal 3 Juni 2015 di PAUD PELITA ILMU Kelurahan Mrican Kecamatan Mojoroto, Kediri dari 10
Ibu yang mempunyai anak usia 1-3 Tahun terdapat 10 anak diantaranya masih memiliki kebiasaan yang kurang tepat dalam buang air besar dan buang air kecil. Misalnya buang air besar dan buang air kecil dicelana tidak memberi tahu ibu sebanyak 2 anak (20\%), buang air kecil dan buang air besar sambil menangis sebanyak 5 anak (50\%) dan buang air besar dan kecil dengan bantuan dari orang tua sebesar 1 anak $(10 \%)$ dan anak yang sudah bisa melakukan buang air besar dan kecil sebanyak 2 anak (20\%). Terlihat juga perilaku yang kurang tepat yang dilakukan oleh ibu ketika menghadapi anak yang buang air besar dan buang air kecil di celana yaitu ibu terlihat kurang tanggap jika anaknya buang air besar dan buang air kecil, marah dan membentak anak terkadang memukul anak. Kondisi ini mungkin disebabkan karena pengetahuan ibu yang kurang mengenai cara melatih buang air besar dan buang air kecil pada anak, dari hasil wawancara dengan 10 ibu, hanya 2 ibu yang mengerti terkait toilet training, mulai dari pengertian, manfaat, cara melatih dan waktu melatih toilet training pada anak sedangkan 8 ibu-ibu yang lainnya tidak mengetahui tentang toilet training.

Kurangnya informasi tentang toilet training dan kurangnya pengetahuan orang tua tentang toilet training menyebabkan orang tua memberikan sikap negatif dalam melatih toilet training pada anak bahkan ada juga yang tidak pernah memberikan latihan toilet training pada anaknya. Faktor yang dapat mempengaruhi kegagalan toilet training antara lain : Tingkat pengetahuan yang kurang, serta segi ekonomi yang kurang mendukung, adanya ketegangan hubungan ibu dan anak dalam kesiapan secara fisik. Kegagalan toilet training ini dapat terjadi karena adanya perlakuan atau aturan yang ketat bagi orang tua kepada anaknya sehingga mengganggu kepribadian anak.(Lukmawati,2014)

Dalam mengatasi masalah ini toilet training di butuhkan kesabaran orang tua untuk melatih anaknya, orang tuga berperan sebagai pendidik merupakan tokoh sentral demi tahap perkembangan anak. Peran orang tua sangat penting karena mempunyai tanggung jawab dalam pembentukan kepribadian dan memberikan pendidikan 
pada anak sehingga di butuhkan pengetahuan dan sikap orang tua dalam mendukung toilet training

\section{METODE}

Jenis penelitian yang di gunakan tipe jenis penelitian korelasi. Desain penelitian yang digunakan adalah korelasi tentang hubungan tingkat pengetahuan dengan sikap orang tua tentang Toilet Training pada anak usia toddler 1-3 tahun di PAUD PELITA ILMU Kelurahan Mrican Kecamatan Mojoroto,Kediri dengan pendekatan cross sectional. Penelitian ini dilaksanakan pada bulan Juli 2015 dengan populasi berjumlah 23 ibu yang mempunyai anak usia 1-3 Tahun HASIL

a. Pengetahuan Orang Tua Tentang Dampak Toilet Training pada Anak Usia Toddler (1-3 Tahun)

\begin{tabular}{clcc}
\hline No & $\begin{array}{c}\text { Sumber } \\
\text { Informasi }\end{array}$ & Frekuensi & Persentase \\
\hline 1 & Baik & 21 & $91,3 \%$ \\
2 & Cukup & 2 & $8,7 \%$ \\
3 & Kurang & 0 & 0 \\
\hline & Jumlah & $\mathbf{2 3}$ & $\mathbf{1 0 0 \%}$ \\
\hline
\end{tabular}

Sumber : Data Penelitian, Juli 2015

b. Sikap Orang Tua Tentang Toilet Training Pada Anak Usia Toddler (1-3 Tahun)

\begin{tabular}{clcc}
\hline $\mathbf{N}$ & $\begin{array}{l}\text { Sumber } \\
\text { o. }\end{array}$ & $\begin{array}{c}\text { Frekue } \\
\text { Informasi }\end{array}$ & $\begin{array}{c}\text { Persentas } \\
\text { e }\end{array}$ \\
\hline 1 & Mendukung & 15 & $65,2 \%$ \\
2 & Cukup & 7 & $30,4 \%$ \\
& Mendukung & & \\
3 & Kurang & 1 & $4,3 \%$ \\
& Mendukung & & \\
\hline & Jumlah & $\mathbf{2 3}$ & $\mathbf{1 0 0 \%}$ \\
\hline
\end{tabular}

Sumber : Data Penelitian, Juli 2015

c. Hubungan Tingkat Pengetahuan dengan Sikap Orang Tua Tentang Toilet Training Pada Anak Usia Toddler (1-3 Tahun)

\begin{tabular}{|c|c|c|c|c|c|}
\hline \multirow{3}{*}{$\begin{array}{c}\text { Katagor } \\
\text { Pengeta } \\
\text { huan }\end{array}$} & \multicolumn{3}{|c|}{ Katagori Sikap } & \multirow{3}{*}{ Total } & \multirow{3}{*}{$\begin{array}{c}\text { Persent } \\
\text { ase }\end{array}$} \\
\hline & & Cukup & $\underset{\text { ng }}{\text { Kura }}$ & & \\
\hline & $\begin{array}{l}\text { Mendu } \\
\text { kung }\end{array}$ & $\begin{array}{c}\text { Menduku } \\
\text { ng }\end{array}$ & $\begin{array}{l}\text { Mend } \\
\text { ukun } \\
\text { g }\end{array}$ & & \\
\hline Baik & 15 & 6 & 0 & 21 & $\begin{array}{c}91,3 \\
\%\end{array}$ \\
\hline Cukup & 0 & 1 & 1 & 2 & $8,7 \%$ \\
\hline
\end{tabular}

3 | Jurnal Kebidanan Dharma Husada Vol. 5, No. 1 April 2016 di PAUD PELITA ILMU Kelurahan Mrican Kecamatan Mojoroto, Kediri. Pemilihan sampel dilakukan dengan total sampling sejumlah 23 responden. Dalam penelitian ini instrumen yang di gunakan adalah kuesioner. Analisa data yang di gunakan dalam penelitian ini adalah analisis data univariat dan analisis data bivariat. Dalam kegiatan ini peneliti melakukan distribusi frekuensi dengan menggunakan tehnik analisa univariat yaitu mendeskripsikan variabel independen (bebas) pengetahuan dan variabel dependen (tergantung) yaitu sikap Analisa Bivariat uji yang digunakan pada penelitian ini menggunakan uji spearman rank 


\begin{tabular}{lccccc}
$\begin{array}{l}\text { Kuran } \\
\mathrm{g}\end{array}$ & 0 & 0 & 0 & 0 & 0 \\
Total & 15 & 7 & 1 & 23 & $\begin{array}{c}100 \\
\%\end{array}$ \\
$\begin{array}{l}\text { Persen } \\
\text { tase }\end{array}$ & $\begin{array}{c}65,2 \\
\%\end{array}$ & $30,4 \%$ & $\begin{array}{c}4,3 \\
\%\end{array}$ & $\begin{array}{c}100 \\
\%\end{array}$ & \\
\hline
\end{tabular}

Sumber : Data Penelitian,Juli 2015

Berdasarkan uji Spearman Rank diperoleh hasil perhitungan dengan nilai signifikan $\mathrm{P}$ value $=$ 0,015 sedangkan $\alpha=0,05$. Oleh karena nilai signifikan lebih kecil dari $\alpha=0,05$ maka $\mathrm{H}_{1}$ diterima, dengan demikian ada hubungan antara pengetahuan orang tua dengan sikap orang tua tentang Toilet Training pada anak usia toddler (1-3 tahun) di PAUD PELITA ILMU

Hasil Koefisien Korelasi sebesar 0,691 menunjukkan bahwa hubungan antara dua variabel kuat yang artinya tingkat pengetahuan dengan sikap orang tua tentang Toilet Training pada anak usia toddler (1-3 tahun) di PAUD PELITA ILMU Kelurahan Mrican Kecamatan Mojoroto Kediri memiliki hubungan yang kuat dan hasil korelasi yang positif $(+)$ menunjukkan bahwa adanya korelasi sejajar atau "Makin baik tingkat pengetahuan maka makin mendukung sikap orang tua tentang Toilet Training pada anak usia toddler (1-3 tahun) di PAUD PELITA ILMU Kelurahan Mrican Kecamatan Mojoroto Kediri.

Menurut Azwar (2002) adanya informasi baru mengenai suatu hal memberikan landasan kognitif baru bagi terbentuknya sikap terhadap hal tersebut. Menurut Notoadmodjo (2003) pengetahuan yang baru akan menimbulkan respon batin dalam bentuk sikap terhadap sesuatu yang diketahui. Sehingga informasi yang di dapatkan responden melalui media massa akan semakin meningkatkan pengetahuan responden melalui media massa akan semakin meningkatkan pengetahuan responden yang akhirnya akan terbentuk sikap yang cukup mendukung tentang Toilet Training

Pengetahuan orang tua dalam melakukan Toilet Training merupakan faktor yang sangat mempengaruhi sikap orang tua dalam mendukung Toilet Training(Armawati,2011) Sikap terhadap nilai-nilai kesehatan tidak selalu terwujud dalam suatu tindakan nyata. Sikap masyarakat terhadap Toilet Training juga dipengaruhi oleh tradisi dan kepercayaan masyarakat terhadap hal-hal yang berkaitan dengan kesehatan sistem nilai yang dianut masyarakat, tingkat pendidikan, tingkat sosial ekonomi.

Sikap kepedulian orang tua terhadap kesehatan anak mempengaruhi tindakan dalam mengajarkan kepada anak, mulai dari hal kecil hingga mulai mengajarkan Toilet
Training. Perlunya pengetahuan tentang penerapan Toilet Training kepada anak sejak dini akan memberikan dampak baik bagi kesehatan dan kebiasaan anak (Safaria,2004). Semakin baik sikap orang tua serta semakin dini pengajaran Toilet Training terhadap anak maka akan sangat menentukan kemampuan anak dalam buang air besar maupun buang air kecil pada tempat yang semestinya.

\section{SIMPULAN}

1. Tingkat pengetahuan responden tentang pengertian dan dampak Toilet Training pada anak usia toddler (1-3 Tahun) berpengetahuan baik (91,3\%) setelah dilakukan pendidikan kesehatan mengenai Toilet Training.

2. Sikap responden tentang Toilet Training pada anak usia toddler (1-3 Tahun) adalah sebagian besar $(62,5 \%)$ bersikap positif di pengaruhi oleh pengalaman pribadi.

3. Hubungan Tingkat Pengetahuan dengan sikap orang tua tentang Toilet Training pada anak usia toddler (1-3 Tahun ) menunujukan adanya tingkat hubungan,yaitu semakin tinggi tingkat pengetahuan maka sikap juga semakin baik. 


\section{DAFTAR PUSTAKA}

A, Aziz Alimul Hidayat. (2007). Metode Penelitian Kebidanan Teknik Analisa Data. Jakarta: Salemba Medika

Arikunto, Suharsimi, (2006). Prosedur Penelitian Suatu Pendekatan Praktik. Jakarta: Rineka Cipta

Alexandra, Vermandel. (2008). Toilet Training of Healthy Young Toddlers: A Randomized Trial Between a Daytime Wetting Alarm and Timed Potty Training. Journal of Develop-mental \& Behavioral Pediatrics, 29 (3): 191196

Alimul Hidayat, A. Aziz. (2005). Pengantar Ilmu Keperawatan Anak 1. Jakarta: Salemba Medika

Armawati, Ni made, (2011). Perubahan Sikap Ibu tentang Toilet Training Anak Usia 1-3 Tahun. Jurnal Penelitian Kesehatan Suara Forikes

Azwar, S. (2000). Sikap Manusia: Teori dan Pengukuran. Yogyakarta: Liberty

Azwar, Saifudin. (2002). Sikap Manusia: Teori dan Pengukuranya. Edisi 2. Jogyakarta: Pustaka Pelajar

Blum, N. J., Taubman, B., dan Nemeth, N. (2003). Relationship Between Age at Initiation of Toilet Training and Duration of Training: A Prospective Study of Pediatrics

Dewi Cintya Rizky. (2015). Teori \& Konsep Tumbuh Kembang Bayi, Toodler, Anak dan Usia Remaja. Yogjakarta: Nuha Medika

Djaali dan Muljono. (2008). Pengukuran Dalam Bidang Pendidikan. PT. Refika Aditama

Friedman, Marlyn N. (2000). Keperawatan keluarga Edisi 3. Jakarta: EGC
Gilbert, Jane. (2003). Latihan Toilet Training. Diterjemahkan oleh: Widyanto Susanto. Jakarta: Erlangga

Gray, John. (2001). Chidren are From Heaven, Terj, B. Dicky Setiadi, AnakAnak Berasal dari Surga; Jakarta: Gramedia

Hikmawati, Isna. (2011). Promosi Kesehatan Untuk Kebidanan. Yogjakarta: Nuha Medika

Lukmanawati, Beni (2014). Penyuluhan terhadap sikap ibu dalam memberikan toilet training pada anak. Jurnal kesehatan masyarakat

Nursalam. (2008). Konsep dan Penerapan Metodelogi Penelitian. Jakarta: Info Medika

Nursalam. (2003). Konsep \& Penerapan Metodelogi Penelitian Ilmu Keperawatan: Pedoman Skripsi, Tesis, dan Instrumen Penelitian Keperawatan. Jakarta. Salemba Medika

Notoatmodjo, S. (2003). Pendidikan dan Perilaku Kesehatan. Jakarta: Rineka Cipta

Notoatmodjo, S. (2007). Metodologi Penelitian Kesehatan. Jakarta: Rineka Cipta

Notoatmodjo, Soekidjo. 2005. Metodelogi Penelitian Kesehatan. Jakarta: PT. Rineka Cipta

Purwanto, Heri. (2010). Pengantar Perilaku Manusia Untuk Keperawatan. Jakarta: Salemba Medika

Safaria, Triamas. (2004). Terapi KognitifPerilaku Untuk Anak. Yogjakarta: Graha Ilmu

Soetjiningsih. (2004). Tumbuh Kembang Remaja dan Permasalahanya. Jakarta: PT. Rhineka Cipta 
Sugiyono. (2005). Metode Penelitian

Kuantitatif Kualitatif. Bandung: CV

Alfa Beta

Sulistyo-Basuki. (2006). Metodelogi

Penelitian. Jakarta: Wedatama Widya Sastra dan Fakultas Ilmu Pengetahuan Budaya Universitas Indonesia
Yani, Ahmad (2014). Hubungan antara tingkat pengetahuan ibu dengan pelaksanaan toilet training secara mandiri pada anak usia 1-3 tahun. Program studi (S1). Stikes darul azhar batu licin

Yupi, Supartini. (2004). Buku Ajar Konsep Keperawatan Anak. Jakarta: Salemba Medika 
